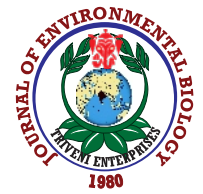

\title{
Influence of elevated temperature on the fitness of Diamondback moth, Plutella xylostella (L.) in cauliflower
}

\author{
K. Haripriya', J. S. Kennedy ${ }^{1 *}$, V. Geethalakshmi ${ }^{2}$ and D. Rajabaskar' \\ ${ }^{1}$ Department of Agricultural Entomology, Tamil Nadu Agricultural University, Coimbatore-641 003, India \\ ${ }^{2}$ Agro Climate Research Centre, Tamil Nadu Agricultural University, Coimbatore-641 003, India \\ *Corresponding Author Email : jskennedy@tnau.ac.in
}

\section{Abstract}

Aim: To understand the effect of elevated temperature on the bionomics and fitness parameters of Plutella xylostella which would help in predicting the population growth rates and formulating appropriate management tactics.

Methodology: In the present investigation, the fitness parameters of diamondback moth were studied at six different temperatures $\left(31,32,33,34,35\right.$ and $\left.36^{\circ} \mathrm{C}\right)$ in cauliflower in Open Top Chambers. Observations were recorded on the survival, longevity and fecundity at daily interval. The raw data on bionomics and life table parameters were analyzed using TWO-SEX-MS chart.

Results: The total life cycle of $P$. xylostella was longer at $31^{\circ} \mathrm{C}$ and it declined with increasing temperatures. However, $P$. xylostella did not complete its development at 35 and $36{ }^{\circ} \mathrm{C}$. The intrinsic rate of increase $\left(r_{m}\right)$ increased from 0.22 at $31^{\circ} \mathrm{C}$ to 0.28 at elevated temperature of $34^{\circ} \mathrm{C}$. Temperature also had a significant effect on the net reproductive rate $\left(R_{0}\right)$, Gross Reproductive Rate (GRR) and finite rate of increase $(\lambda)$.

Interpretation: The fitness parameters will help to predict the change that occur in $P$. xylostella population due to climate change and global warming.

Key words: Diamondback moth, Life table, Population dynamics, Temperature

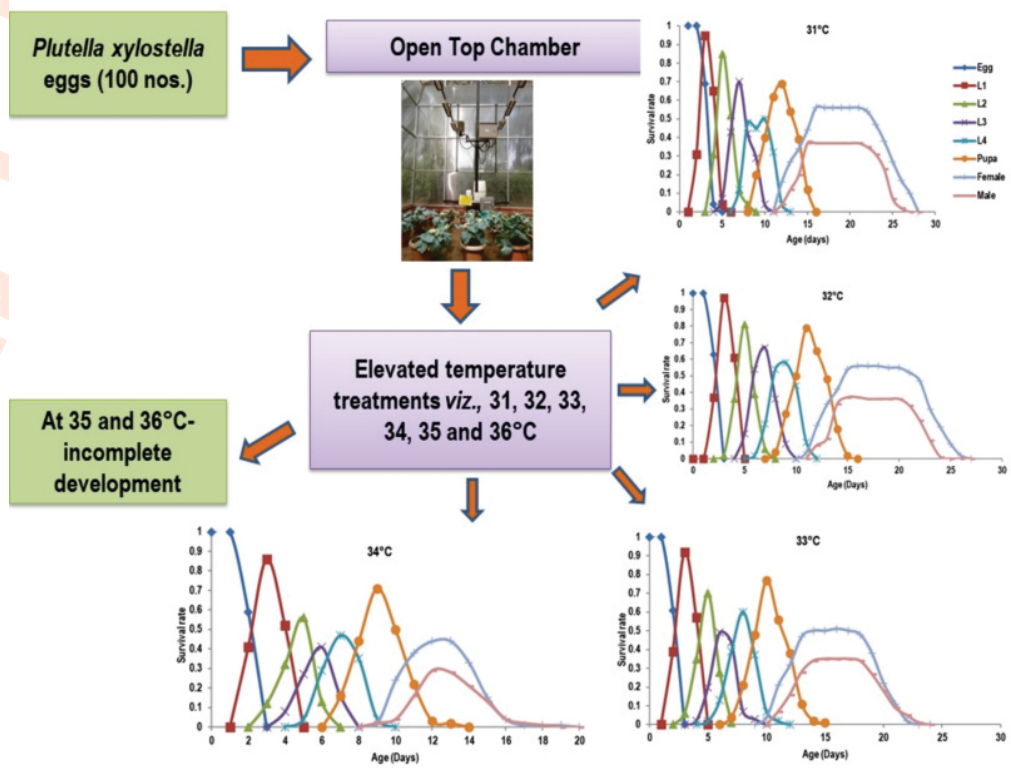

How to cite : Haripriya K., J. S. Kennedy, V. Geethalakshmi and D. Rajabaskar, Influence of elevated temperature on the fitness of Diamondback moth, Plutella xylostella (L.) in cauliflower. J. Environ. Biol., 42, 1106-1113 (2021). 


\section{Introduction}

Diamondback moth, Plutella xylostella (L.) (Lepidoptera: Plutellidae) is a devastating pest of cruciferous vegetable crops across the world (Garrad et al., 2016, Jaleel et al., 2019, Steinbach et al., 2017). The yield loss due to this destructive insect pest is estimated to be around 50- 80\% (Dhaliwal et al., 2010). Globally, 4-5 billion US dollars have been spent on the management of $P$. xylostella (Zalucki et al., 2012). The ability to complete number of generations per year, higher reproductive rate and insecticide resistance has made $P$. xylostella management difficult (Furlong et al., 2013, Gu et al., 2010, Shelton and Wyman, 1992).

Insects are poikilothermic organisms, its growth, reproduction, survival and abundance are influenced by factors like temperature and photoperiod (Awmack and Leather, 2002, Malaquias et al., 2010, Hallman and Denlinger, 1998). Thermal conditions required for the successful development of the pest vary in different ecological regions (Chen et al., 2017, Gomi et al., 2003). Study of such variations are the need of the moment since global warming is likely to increase by $1.5^{\circ} \mathrm{C}$ between 2030 and 2052 (IPCC, 2018).

Precise knowledge of insect adaptations to changing climatic condition plays a vital role in effective management practices (Vargas et al., 2000). Life table parameters like intrinsic rate of increase $\left(r_{m}\right)$ are important population measurement which helps to identify suitable Integrated Pest Management (Huang and Chi, 2013; Southwood and Henderson, 2000).

The effect of temperature on the biology of $P$. xylostella has been studied across the globe (Golizadeh et al., 2009; Liu et al., 2002; Shirai, 2000). However, most studies have been carried out under more extensive temperature variations, i.e., $10^{\circ} \mathrm{C}$ to $30^{\circ} \mathrm{C}$. As we are impending towards the era of climate change, it is essential to know the demography of insect pests even with infinite simal temperature variations. Hence, in the present study, the fitness parameters of diamondback moth were studied on six sequential temperature treatments by using two-sex life table. Exploring the relationship between temperature and $P$. xylostella population will be useful for formulating accurate management practices in the future.

\section{Materials and Methods}

The seed of cauliflower (Brassica oleracea var. botrytis) variety Arka Kanti was grown in pots in a greenhouse and used for the experiments. The mother culture of $P$. xylostella larvae and pupae were collected from the cauliflower fields of Thondamuthur and Narasipuram, Coimbatore during February 2019. The collected larvae were reared on the leaves of cauliflower at $28 \pm$ $2^{\circ} \mathrm{C}, 70 \pm 5 \% \mathrm{RH}$ in plastic containers $(13 \times 15 \times 11 \mathrm{~cm})$ covered with a fine muslin cloth. The pupae formed were placed in adult emergence cage $(60 \times 60 \times 60 \mathrm{~cm})$ which consisted clear, plexiglass on one side and remaining sides made of fine nylon mesh gauze. An opening was made on one side for providing fresh leaves and food. Honey solution (10\%) was soaked in a cotton wick $(10 \mathrm{~cm})$ and given to adult as feed along with fresh cauliflower leaves (Golizadeh et al., 2009). The cage was covered with black muslin cloth for egg laying. Every 24h, the leaves with freshly laid eggs were collected from the cage and used for experiments.

A cubical open top chamber was built with high-quality multilayer polycarbonate sheets (4-6 mm thickness) partially opened top side $4 \mathrm{~m} \times 4 \mathrm{~m} \times 4 \mathrm{~m}$ made with galvanized iron (GI). The structure was outfitted with humidity and temperature supervising control and wireless signal transmission amenities along with SCADA (Supervisory Control and Data Acquisition) integration technology. Ceramic IR heaters could elevate the temperature around $10^{\circ} \mathrm{C}$ than control (ambient condition) autonomously in each OTC. Using SCADA system, a control signal from the controller was received by heaters which were a final control element (FCE). Different temperature regimes were attained correspondent to set temperature. Cauliflower plants were grown in pots for each temperature treatments in open top chambers.

Developmental parameters of $P$. xylostella were studied at six constant temperatures $\left(31,32,33,34,35\right.$ and $\left.36^{\circ} \mathrm{C}\right)$ in separate open top chambers. For studying the fitness parameters, ten $P$. xylostella eggs were collected from the surface of the leaf using small camel hair brush and placed on a leaf disc on water - soaked cotton in each 10 Petri dishes. A total of 100 eggs were examined at each temperature. A circular hole of $3 \mathrm{~cm}$ diameter fitted with fine nylon mesh was made on the lid for ventilation. The eggs were carefully examined until hatching. Each egg was noted as a replication. The newly emerged I instar larvae from each temperature treatment were placed individually on cauliflower leaf disc placed on water - soaked cotton in Petri dishes ( $4.5 \mathrm{~cm}$ dia, $4 \mathrm{~cm}$ ht). Fresh cauliflower leaves were given every day during the experimental period. The mortality, developmental time of each instar and life cycle of $P$. xylostella were recorded at each temperature treatment.

Fecundity and longevity of $P$. xylostella adults were examined at four constant temperatures $\left(31,32,33\right.$ and $\left.34^{\circ} \mathrm{C}\right)$. Temperature 35 and $36^{\circ} \mathrm{C}$ were excluded due to $100 \%$ mortality. Fifteen mating pairs were used for each treatment. Each pair was released in glass tubes covered with fine cloth. Crushed aluminium foil sheets swabbed with cauliflower leaf extract was provided as a substrate for oviposition. Egg laden foil sheets were replaced with new aluminium foil sheets every $24 \mathrm{hr}$ and the number of eggs laid were counted until adults died.

The biological parameters of $P$. xyllostella were analyzed according to age- stage, two sex life table program TWO-SEXMS chart (Chi, 2014). Age specific fecundity $\left(m_{x}\right)$, age-specific survival rate $\left(I_{x}\right)$ and population parameters were calculated according to Huang and Chi (2012). The intrinsic rate of increase $\left(r_{m}\right)$ value was calculated as 


$$
r_{m}=\log _{e} \frac{R_{0}}{T_{c}}
$$

The $/ x, m x$ and $\mathrm{R}_{0}$ vales are calculated using

$$
\begin{gathered}
l_{x}=\sum_{j=1}^{k} S_{x j} \\
m_{x=} \sum_{j=1}^{k} s_{x j} f_{x j} / \sum_{j=1}^{k} s_{x j} \\
R_{0}=\sum_{x=\alpha}^{\beta} l_{x} m_{x}
\end{gathered}
$$

The Gross Reproductive Rate (GRR) was calculated by the formula: $G R R=\sum m_{x}$. Mean separations of oviposition period and adult longevity were done by Duncan's Multiple Range Test (DMRT) using IBM SPSS v. 22 statistical program. Similar procedures were used for other parameters $\left(r_{m}, \lambda, R_{0}, T, G R R\right.$ and $\left.t\right)$.
The mean values of life table parameters were subjected to Bootstrap analysis $(n=1,00,000)$ and the standard errors were estimated.

\section{Results and Discussion}

Life table is an important analytical tool to understand the growth, development and reproduction of insects under varying conditions. To get accurate estimates of fitness parameters, bootstrap technique was utilized with $n=1,00,000$ and the means were used for calculating the standard errors (Huang and Chi, 2012). Insects can survive under a wide range of temperatures. The effect of temperature on the growth and development of various insects has been studied (Golizadeh et al., 2009; Manikandan et al., 2013; Chen etal., 2017; Soh et al., 2018).

P. xylostella completed its development at temperatures between 31 and $34^{\circ} \mathrm{C}$. All the third instar larval stages died at $35^{\circ} \mathrm{C}$ whereas at $36^{\circ} \mathrm{C}$, the eggs of $P$. xylostella did not hatch. The egg development time was significantly shorter at $35^{\circ} \mathrm{C}$ than other temperatures $(P<0.001)$. The duration of first, second, third and fourth instar larvae were significantly longer at the minimum temperature treatment of $31^{\circ} \mathrm{C}(1.99,1.91,2.07$ and 2.03 days $)$
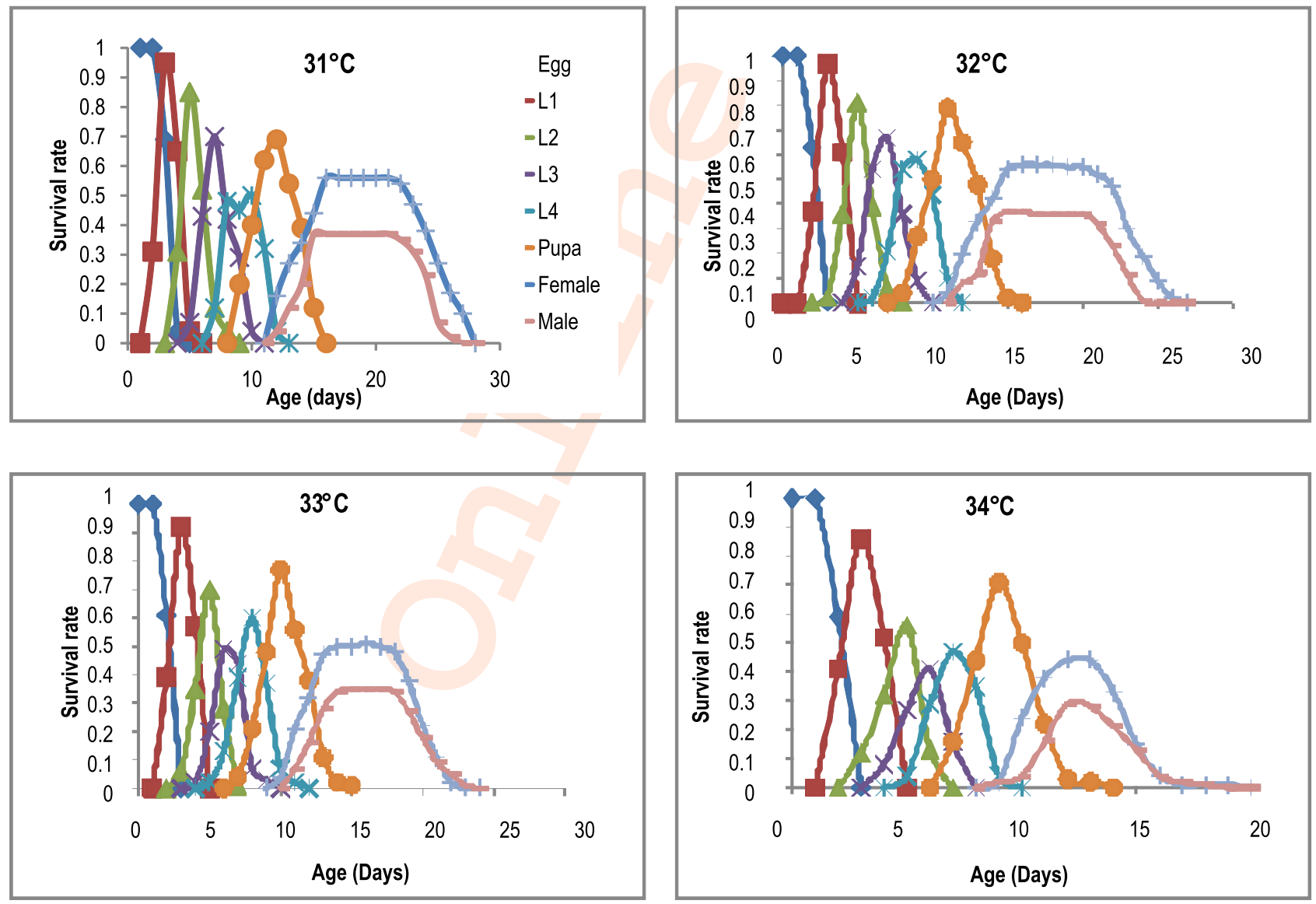

Fig 1. Influence of four different temperatures on the age - stage - specific survival rate $\left(S_{x}\right)$ ofPlutella $x y l o s t e l l a ; ~ L 1=1^{\text {st }} \operatorname{Instar}, L 2=2^{\text {nd }} \operatorname{lnstar}$, $L 3=3^{\text {rd }}$ Instar, L4 $=4^{\text {th }}$ Instar. 
Table 1 : Influence of different temperatures on the biological traits of Plutella xylostella in cauliflower

\begin{tabular}{|c|c|c|c|c|c|c|c|}
\hline \multirow{2}{*}{$\begin{array}{l}\text { Parameters } \\
\text { (Days) }(n=100)\end{array}$} & \multicolumn{5}{|c|}{ Temperature $\left({ }^{\circ} \mathrm{C}\right)$} & \multirow[t]{2}{*}{$F$} & \multirow[t]{2}{*}{$\mathbf{P}$} \\
\hline & 31 & 32 & 33 & 34 & 35 & & \\
\hline Egg & $2.73 \pm 0.05^{b}$ & $2.61 \pm 0.05^{b}$ & $2.60 \pm 0.04^{b}$ & $2.63 \pm 0.05^{b}$ & $2.56 \pm 0.05^{\mathrm{a}}$ & 11.26 & $<0.001$ \\
\hline I instar & $1.99 \pm 0.01^{\circ}$ & $1.97 \pm 0.02^{\circ}$ & $1.93 \pm 0.03^{\circ}$ & $1.86 \pm 0.04^{b}$ & $1.89 \pm 0.04^{\mathrm{a}}$ & 3.208 & $<0.001$ \\
\hline II instar & $1.91 \pm 0.07^{\mathrm{e}}$ & $1.71 \pm 0.07^{d}$ & $1.50 \pm 0.06^{c}$ & $1.27 \pm 0.05^{b}$ & $1.35 \pm 0.10^{\mathrm{a}}$ & 4.807 & $<0.001$ \\
\hline III instar & $2.07 \pm 0.06^{d}$ & $1.91 \pm 0.05^{d}$ & $1.42 \pm 0.06^{c}$ & $1.13 \pm 0.04^{b}$ & $1.14 \pm 0.14^{\mathrm{a}}$ & 3.829 & $<0.001$ \\
\hline IV instar & $2.03 \pm 0.05^{d}$ & $2.04 \pm 0.05^{d}$ & $1.82 \pm 0.05^{\circ}$ & $1.44 \pm 0.06^{\mathrm{b}}$ & $1.00 \pm 0.01^{\mathrm{a}}$ & 4.251 & $<0.001$ \\
\hline Pupa & $3.16 \pm 0.05^{\mathrm{d}}$ & $3.12 \pm 0.05^{d}$ & $2.94 \pm 0.06^{c}$ & $2.67 \pm 0.07^{b}$ & $0.00 \pm 0.00^{\mathrm{a}}$ & 4.603 & $<0.001$ \\
\hline Pre-adult & $13.91 \pm 0.14^{d}$ & $13.39 \pm 0.18^{\circ}$ & $12.23 \pm 0.13^{b}$ & $10.93 \pm 0.11^{a}$ & - & 198.76 & $<0.001$ \\
\hline
\end{tabular}

Means in the same row followed by same letter are not significantly different $(P>0.05)$ using bootstrap test.
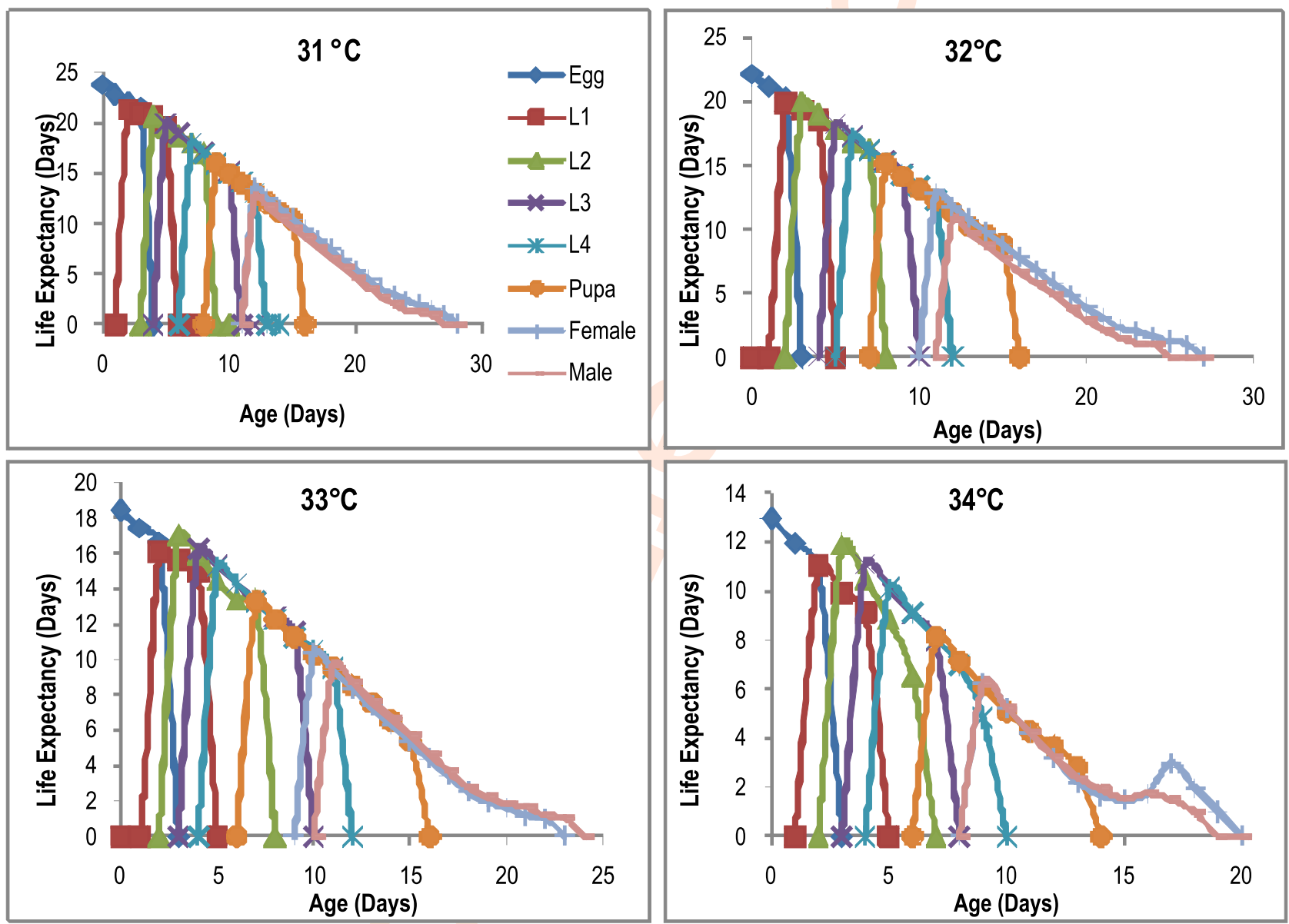

Fig. 2. Influence of different temperatures on age-stage-specific life expectancy $\left(e_{x}\right)$ of Plutellaxylostella; $L 1=1^{\text {st }} \operatorname{Instar,~} L 2=2^{\text {nd }} \operatorname{lnstar}, L 3=3^{\text {rd }}$ Instar, L4 $=4^{\text {th }}$ Instar.

and the duration steadily reduced at higher temperature of $35^{\circ} \mathrm{C}$ $(1.89,1.35,1.14$ and 1.00 days).The pupal duration lasted for about $3.16 \pm 0.05$ days at $31^{\circ} \mathrm{C}$ whereas it significantly reduced to 2.67 days at $34^{\circ} \mathrm{C}(\mathrm{P}<0.001)$ (Table 1$)$ (Fig. 1 and 2$)$.

Similarly, in cabbage and cauliflower the survival rate of P. xylostella was reduced at $35^{\circ} \mathrm{C}$ (Golizadeh et al., 2009).
Shirai (2000) found that $20-25^{\circ} \mathrm{C}$ was the favorable condition for the reproduction of $P$. xylostella, while in our study the fecundity can be observed up to $34^{\circ} \mathrm{C}$. Also, Liu et al. (2002) concluded that $P$. xylostella developed successfully from egg to adult stage at temperatures ranging from $8-32^{\circ} \mathrm{C}$ and there was only partial development at temperatures ranging from 34 $-40^{\circ} \mathrm{C}$. 

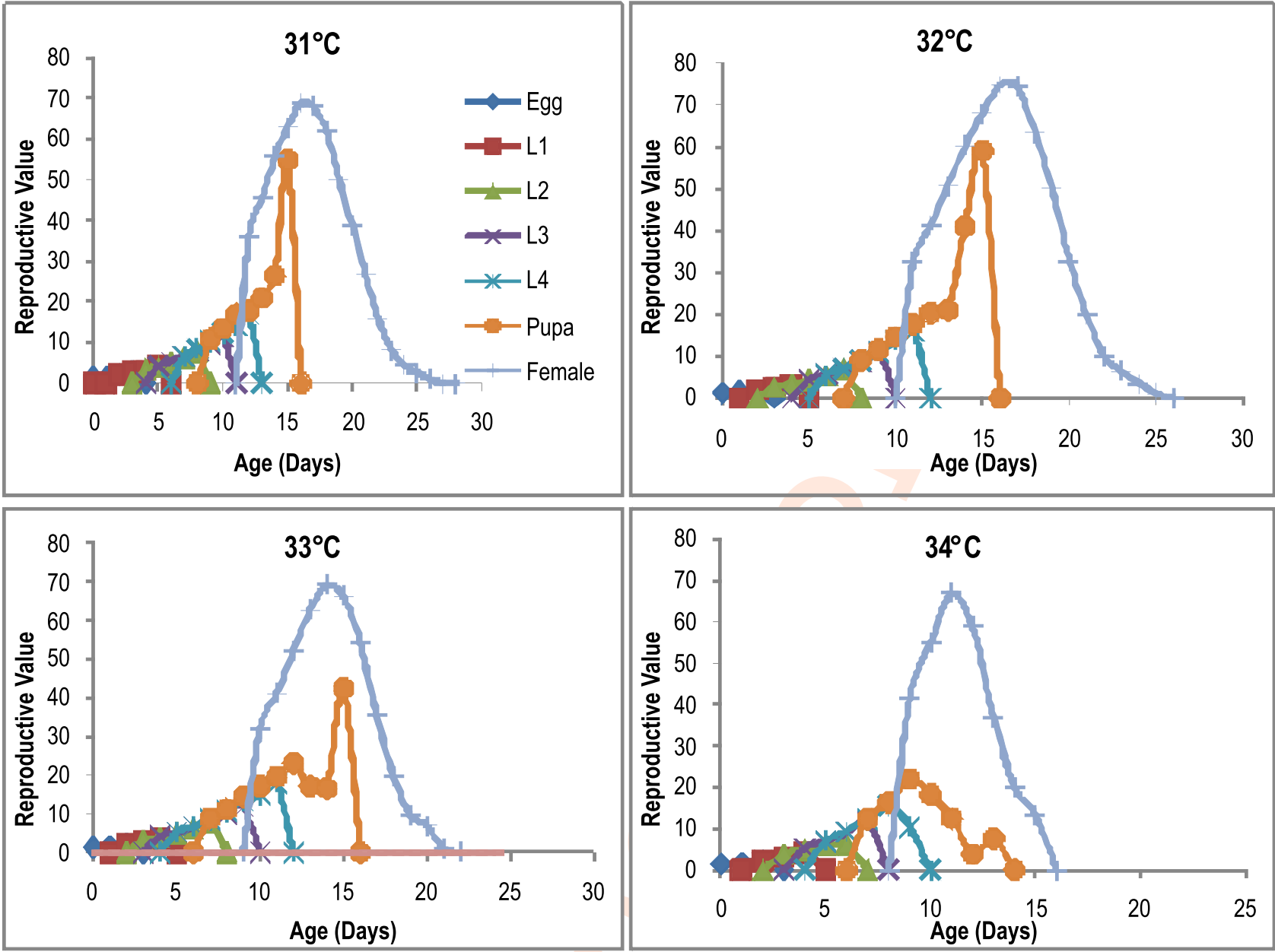

Fig. 3. Age-stage reproductive value $\left(V_{x}\right)$ of Plutella $x y l o s t e l l a ; ~ L 1=1^{\text {st }} \operatorname{Instar}, L 2=2^{\text {nd }} \operatorname{Instar}, L 3=3^{\text {rd }} \operatorname{Instar}, L 4=4^{\text {th }} \operatorname{Instar}$.

Table 2: Oviposition period of Plutella xylostella in cauliflower at different temperatures

\begin{tabular}{|c|c|c|c|c|c|c|}
\hline \multirow{2}{*}{$\begin{array}{l}\text { Parameters } \\
\text { (Days) }(n=100)\end{array}$} & \multirow[b]{2}{*}{$31^{\circ} \mathrm{C}$} & \multicolumn{3}{|c|}{ Temperature } & \multirow[t]{2}{*}{$F$} & \multirow[t]{2}{*}{$P$} \\
\hline & & $32^{\circ} \mathrm{C}$ & $33^{\circ} \mathrm{C}$ & $34^{\circ} \mathrm{C}$ & & \\
\hline Male longevity & $10.62 \pm 0.14^{d}$ & $9.14 \pm 0.15^{c}$ & $8.11 \pm 0.10^{b}$ & $3.87 \pm 0.11^{a}$ & 1649.30 & $<0.001$ \\
\hline Female longevity & $11.61 \pm 0.08^{\mathrm{d}}$ & $10.54 \pm 0.13^{c}$ & $8.35 \pm 0.10^{b}$ & $4.60 \pm 0.09^{\mathrm{a}}$ & 447.70 & $<0.001$ \\
\hline APOP & $1.73 \pm 0.11^{\circ}$ & $1.93 \pm 0.12^{b c}$ & $1.53 \pm 1.33^{\mathrm{b}}$ & $0.87 \pm 0.09^{\mathrm{a}}$ & 0.953 & 0.05 \\
\hline TPOP & $15.6 \pm 0.42^{d}$ & $14.87 \pm 0.39^{\circ}$ & $13.66 \pm 0.25^{b}$ & $11.2 \pm 0.22^{\mathrm{a}}$ & 6.085 & $<0.001$ \\
\hline Oviposition & $8.6 \pm 0.21^{\mathrm{d}}$ & $7.47 \pm 0.16^{c}$ & $5.66 \pm 0.15^{b}$ & $2.66 \pm 0.15^{\mathrm{a}}$ & 1.084 & 0.399 \\
\hline $\begin{array}{l}\text { Fecundity } \\
\text { (total eggs/ female) }\end{array}$ & $150.86 \pm 19.32^{c}$ & $142.80 \pm 3.62^{b c}$ & $117.07 \pm 5.27^{\mathrm{ab}}$ & $100.33 \pm 8.27^{a}$ & 1.205 & 0.307 \\
\hline
\end{tabular}

Means in the same row followed by same letter are not significantly different $(P>0.05)$ using bootstrap test.

Adult pre-oviposition period (APOP) did not vary significantly between the temperatures $31^{\circ} \mathrm{C}$ and $34^{\circ} \mathrm{C}(\mathrm{P}=$ 0.514 ) and total pre-oviposition period (TPOP) ranged from 15.6 \pm 0.42 days to $11.2 \pm 0.22$ days when the temperature increase from $31^{\circ} \mathrm{C}$ to $34^{\circ} \mathrm{C}$, respectively $(\mathrm{P}<0.001)$. The oviposition days of $P$. xylostella were inversely proportional with the increasing temperatures. At $31^{\circ} \mathrm{C}$, the females oviposited for 8.6 days whereas it was decreased to 2.66 days at $34^{\circ} \mathrm{C}$. Similarly, the fecundity reduced from 150.866 eggs per female at $31^{\circ} \mathrm{C}$ to 100.33 eggs per female at $34^{\circ} \mathrm{C}$ (Fig. 3).

The longevity of female is negatively correlated with the increasing temperatures. At $31^{\circ} \mathrm{C}$, the longevity of female was 11.61 days and it significantly abridged to 4.60 days when the temperature was raised to $34^{\circ} \mathrm{C}$. The maximum longevity of male was observed at $31^{\circ} \mathrm{C}$ (10.62 days) and minimum was at $34^{\circ} \mathrm{C}$ 

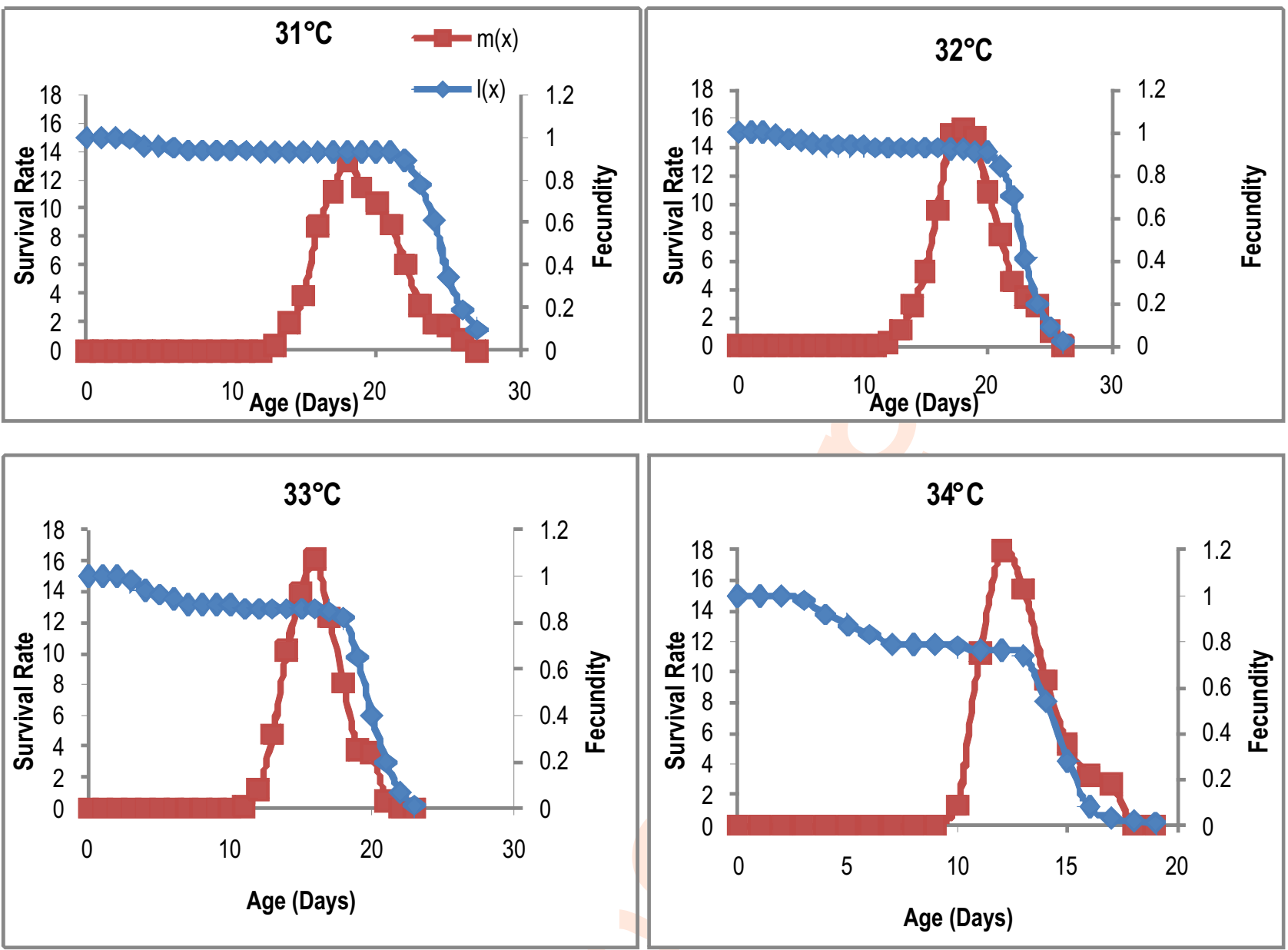

Fig 4: Influence of different temperatures on the survival rate $\left(I_{x}\right)$ and fecundity $\left(m_{x}\right)$ of Plutella xylostella.

Table 3: Influence of different temperatures on the life table parameters of Plutella xylostella

\begin{tabular}{lllllll}
\hline Parameters & \multicolumn{3}{c}{ Temperature } & F & P \\
\cline { 2 - 5 } & $31^{\circ} \mathrm{C}$ & $32^{\circ} \mathrm{C}$ & $33^{\circ} \mathrm{C}$ & $34^{\circ} \mathrm{C}$ & \\
\hline$r_{m}$ & $0.22 \pm 0.001^{\mathrm{a}}$ & $0.23 \pm 0.002^{\mathrm{a}}$ & $0.24 \pm 0.002^{\mathrm{b}}$ & $0.28 \pm 0.007^{\mathrm{c}}$ & 188.00 & $<0.001$ \\
$\lambda$ & $1.25 \pm 0.008^{\mathrm{b}}$ & $1.27 \pm 0.171^{\mathrm{b}}$ & $1.28 \pm 0.003^{\mathrm{b}}$ & $0.32 \pm 0.007^{\mathrm{a}}$ & 4014.61 & $<0.001$ \\
$\mathrm{R}_{0}$ & $74.98 \pm 0.737^{\mathrm{c}}$ & $80.17 \pm 1.355^{\mathrm{d}}$ & $60.90 \pm 0.507^{\mathrm{b}}$ & $42.07 \pm 1.007^{\mathrm{a}}$ & 343.78 & $<0.001$ \\
$\mathrm{~T}$ & $19.13 \pm 0.038^{\mathrm{c}}$ & $18.59 \pm 0.377^{\mathrm{c}}$ & $14.68 \pm 0.122^{\mathrm{b}}$ & $13.25 \pm 0.324^{\mathrm{a}}$ & 94.23 & $<0.001$ \\
$\mathrm{GRR}$ & $83.76 \pm 0.179^{\mathrm{c}}$ & $94.02 \pm 1.663^{\mathrm{d}}$ & $74.58 \pm 1.474^{\mathrm{b}}$ & $62.67 \pm 1.501^{\mathrm{a}}$ & 82.74 & $<0.001$ \\
$\mathrm{t}$ & $3.07 \pm 0.010^{\mathrm{d}}$ & $2.94 \pm 0.016^{\mathrm{c}}$ & $2.77 \pm 0.015^{\mathrm{b}}$ & $2.45 \pm 0.038^{\mathrm{a}}$ & 104.38 & $<0.001$ \\
\hline
\end{tabular}

$r_{m}$ : The intrinsic rate of increase (per day); $\lambda$ : The finite rate of increase (per day); $R_{0}:$ The net reproductive rate (offspring/individual); $T$ : The mean generation time (days); t: Population doubling time; GRR: Gross reproductive rate (offspring); Means in the same row followed by the same letter are not significantly different $(P>0.05)$ using bootstrap test.

(3.87 days) (Table 2). There was an inverse relationship between temperature and age - specific survival rate $\left(I_{x}\right)$ and fecundity $\left(m_{x}\right)$ (Fig.4). Likewise, Garrad et al. (2016) found that P. xylostella reared at $30^{\circ} \mathrm{C}$ have shorter life span than insects reared at any other temperature, suggesting decreased fitness; however, they did produce a large number of eggs in the few days they were alive. 
The fitness parameters of $P$. xylostella were notably affected by the increasing temperatures of $31^{\circ} \mathrm{C}$ to $34^{\circ} \mathrm{C}$. The intrinsic rate of increase $\left(r_{m}\right)$ had increased significantly from 0.22 to 0.28 when temperature increased from $31^{\circ} \mathrm{C}$ to $34^{\circ} \mathrm{C}(\mathrm{P}<$ 0.001). Ngowi et al. (2017) showed that $r_{m}$ value increased from 0.001 at $10^{\circ} \mathrm{C}$ to 0.20 at $30^{\circ} \mathrm{C}$. It had been reported that the preadult and adult development rate varied at different temperatures (Folguera et al., 2010). The development time from an egg to adult, as well as the fecundity of insect pests attributed to the variations in $r_{m}$ value (Badenes-Perez et al., 2005).

The net reproductive rate $\left(R_{0}\right)$ was maximum with 80.14 individuals per female per lifetime at $32^{\circ} \mathrm{C}$ followed by 74.98 individuals per female per lifetime at $31^{\circ} \mathrm{C}$ and lowest $R_{0}$ value of 42.07 individuals per female per lifetime was observed at $34^{\circ} \mathrm{C}$. The longest mean generation time was 19.13 days at $31^{\circ} \mathrm{C}$ compared to the shortest of 13.25 days at $34^{\circ} \mathrm{C}$. The highest GRR value (94.02 numbers of offsprings per day) was found at $32^{\circ} \mathrm{C}$; while lowest ( 62.67 numbers of offsprings per day) at $34^{\circ} \mathrm{C}$ (Table 3).

Jafary-Jahed et al. (2019) found that the net reproductive rate $\left(\mathrm{R}_{0}\right)$ of $P$. xylostella was 65.46 offsprings per individual when larvae were reared on cauliflower at $30^{\circ} \mathrm{C}$, which nearly corroborated with the present finding where the net reproductive rate $\left(R_{0}\right)$ was 74.98 individuals per female per lifetime at $31^{\circ} \mathrm{C}$. The GRR is a measure of rapid increase of population that depends on the number of eggs laid, eggs hatched and adult eclosion, and all these parameters are exaggerated by temperature (Khaliq et al., 2007). In our study, the GRR decreased to 62.67 numbers of offsprings per day when the temperature increased to $34^{\circ} \mathrm{C}$. The population increases only when net reproductive rate will be greater than 1 and $r>0$ (Chen et al., 2017, Southwood and Henderson, 2009). The findings of this study also confirmed the aforesaid theory. The information obtained from the present study can be used for developing forecasting models and formulating optimal integrated pest management strategies in the future era of global climate change.

\section{Acknowledgment}

The authors duly acknowledge the Government of IndiaDepartment of Science and Technology (DST) - International Crops Research Institute for Semi- Arid Tropics (ICRISAT) for providing financial assistance.

\section{Add-on Information}

Authors' contribution: K. Haripriya: Conduct of experiment, data recording and writing of manuscript; J. S. Kennedy: Conceptualization and supervision of research plan; V. Geethalakshmi: Review and finalization of paper, Supervision; D. Rajabaskar: Review and finalization of paper, Supervision.

Research content: The research content is original and has not been published elsewhere
Ethical approval: NotApplicable

Conflict of interest: The authors declare that there is no conflict of interest.

\section{Data from other sources: NotApplicable}

Consent to publish: All authors agree to publish the paper in Journal of Environmental Biology.

\section{References}

Awmack, C.S. and S.R. Leather. Host plant quality and fecundity in herbivorous insects. Ann. Revi. Entomo., 47, 817-844 (2002).

Badenes-Perez, F.R., A.M. Shelton and B.A. Nault: Using yellow rocket as a trap crop for diamondback moth (Lepidoptera: Plutellidae). J. Econ. Ento., 98, 884-890 (2005).

Chen, Q., N. Li, X. Wang, L. Ma, J.-B. Huang and G.-H. Huang. Agestage, two-sex life table of Parapoynx crisonalis (Lepidoptera: Pyralidae) at different temperatures. PloS ONE, 12, 1-12 (2017).

Chi, H.: TWOSEX-MSChart: a computer program for the age stage, twosex life table analysis (2014).

Dhaliwal, G. S., V. Jindal and A.K. Dhawan: Insect pest problems and crop losses: changing trends. Ind. J. Ecol., 37, 1-7 (2010).

Folguera, G., J. Mensch, J.L. Muñoz, S.G. Ceballos, E. Hasson and F. Bozinovic: Ontogenetic stage-dependent effect of temperature on developmental and metabolic rates in a holometabolous insect. $J$. Insect physio., 56, 1679-1684 (2010).

Furlong, M.J., D.J. Wright and L.M. Dosdall. Diamondback moth ecology and management: problems, progress, and prospects. Ann. Revi. Entom., 58, 517-541 (2013).

Garrad, R., D.T. Booth and M.J. Furlong: The effect of rearing temperature on development, body size, energetics and fecundity of the diamondback moth. Bullet. Entomol. Res., 106, 175-181 (2016).

Golizadeh, A., K. Kamali, Y. Fathipour and H. Abbasipour: Life table of the diamondback moth, Plutella xylostella (L.)(Lepidoptera: Plutellidae) on five cultivated brassicaceous host plants. J. AsiaPacific Entomol., 12, 207-212 (2009).

Gomi, T., M. Inudo and D. Yamada: Local divergence in developmental traits within a trivoltine area of Hyphantria cunea Drury (Lepidoptera: Arctiidae). Entomol. Sci., 6, 71-75 (2003).

Gu, X., S. Tian, D. Wang, G. Fei and H. Wei: Interaction between shortterm heat pretreatment and fipronil on 2nd instar larvae of diamondback moth, Plutella xylostella (Linn).Dose-Response. 8, 331-346 (2010).

Hallman, G.J. and D.L. Denlinger: Temperature sensitivity in insects and application in integrated pest management. Westview Press, Boulder., pp. 311 (1998).

Huang, Y.B. and H. Chi: Age - stage, two - sex life tables of Bactrocera cucurbitae (Coquillett)(Diptera: Tephritidae) with a discussion on the problem of applying female age - specific life tables to insect populations. Ins. Sci., 19, 263-273 (2012).

Huang, Y.B. and H. Chi: Life tables of Bactrocera cucurbitae (Diptera: Tephritidae): with an invalidation of the jackknife technique. J. Appl. Entomol., 137, 327-339 (2013).

Jafary-Jahed, M., J. Razmjou, G. Nouri-Ganbalani, B. Naseri, M. Hassanpour and N.C. Leppla: Life table parameters and Oviposition Preference of Plutella xylostella (Lepidoptera: Plutellidae) on six Brassicaceous crop plants. J. Econ. Entomol., $112,932-938(2019)$

Jaleel, W., S. Saeed, Q. Saeed, M.N. Naqqash, M.U. Sial, Q.U. Aine, L. 
Yanyuan, Z. Rui, Y. He and L. Lu: Effects of three different cultivars of cruciferous plants on the age-stage, two-sex life table traits of Plutella xylostella (L.)(Lepidoptera: Plutellidae). Entomol. Res., 49, 151-157 (2019).

Khaliq, A., M.N.R. Attique and A.H. Sayyed: Evidence for resistance to pyrethroids and organophosphates in Plutella xylostella (Lepidoptera: Plutellidae) from Pakistan. Bull. Entomol. Res., 97, 191-200 (2007).

Liu, S.-S., F.-Z. Chen and M.P. Zalucki: Development and survival of the diamondback moth (Lepidoptera: Plutellidae) at constant and alternating temperatures. Environ. Entomol., 31, 221-231 (2002).

Malaquias, J.B., F.S. Ramalho, F.S. Fernandes, J.L. NascimentoJúnior, E.T. Correia and J.C. Zanuncio: Effects of photoperiod on reproduction and longevity of Podisus nigrispinus (Heteroptera: Pentatomidae). Ann. Entomol. Soc. Amer., 103, 603-610 (2010).

Manikandan, N., J.S. Kennedy and V. Geethalakshmi: Effect of elevated temperature on development time of rice yellow stem borer. Ind. J. Sci. Technol., 6, 5563-5566 (2013).

Ngowi, B.V., H.E.Z. Tonnang, E.M. Mwangi, T. Johansson, J. Ambale, P.N. Ndegwa and S. Subramanian: Temperature-dependent phenology of Plutella xylostella (Lepidoptera: Plutellidae): Simulation and visualization of current and future distributions along the Eastern Afromontane. PloS ONE, 12, (2017).

Shelton, A. M., J. A. Wyman, N. L. Cushing, K. Apfelbeck, T. J. Dennehy, S. E. R. Mahr, S. D. Eigenbrode: Insecticide Resistance of
Diamondback Moth (Lepidoptera: Plutellidae) in North America. J. Econom. Entomol., 86, 11-19 (1993).

Shirai, Y.: Temperature tolerance of the diamondback moth, Plutella xylostella (Lepidoptera: Yponomeutidae) in tropical and temperate regions of Asia. Bull. Entomol. Res., 90, 357-364 (2000).

Soh, B.S.B., S. Kekeunou, S. Nanga Nanga, M. Dongmo and H. Rachid: Effect of temperature on the biological parameters of the cabbage aphid Brevicoryne brassicae. Ecol. Evolut., 8, 11819-11832 (2018).

Southwood, T.R.E. and P.A. Henderson: Ecological Methods. $3^{\text {rd }}$ Edn., Blackwell Science, USA, 575 Pages (2000).

Southwood, T.R.E. and P.A. Henderson: Ecological Methods. WileyBlackwell, 592 Pages (2009).

Steinbach, D., G. Moritz and R. Nauen: Fitness costs and life table parameters of highly insecticide-resistant strains of Plutella xylostella (L.)(Lepidoptera: Plutellidae) at different temperatures. Pest Manag. Sci., 73, 1789-1797 (2017)

Vargas, R.I., W.A. Walsh, D. Kanehisa, J.D. Stark and T. Nishida: Comparative demography of three Hawaiian fruit flies (Diptera: Tephritidae) at alternating temperatures. Ann. Entomol. Soc. Amer., 93, 75-81 (2000).

Zalucki, M.P., A. Shabbir, R. Silva, D. Adamson, L. Shu-Sheng and M.J. Furlong: Estimating the economic cost of one of the world's major insect pests, Plutella xylostella (Lepidoptera: Plutellidae), just how long is a piece of string?J. Econ. Entomol., 105, 1115-1129 (2012). 